\title{
Chlamydospore concentration for assessment of Fusarium root rot on common bean
}

\author{
Alessandro Nicoli ${ }^{1}$, Laércio Zambolim ${ }^{1}$, Trazilbo J. Paula Júnior ${ }^{2}$, Rogério F. Vieira ${ }^{2}$, Hudson Teixeira ${ }^{2} \&$ \\ José Eustáquio S. Carneiro ${ }^{3}$
}

${ }^{1}$ Departamento de Fitopatologia, Universidade Federal de Viçosa, 36570-000, Viçosa, MG, Brazil; ${ }^{2}$ Empresa de Pesquisa Agropecuária de Minas Gerais - Epamig, Vila Gianetti 47, 36570-000, Viçosa, MG, Brazil; ${ }^{3}$ Departamento de Fitotecnia, Universidade Federal de Viçosa, 36570-000, Viçosa, MG, Brazil

Author for correspondence: Alessandro Nicoli, e-mail: alessandro.nicoli@ufv.br

\begin{abstract}
Fusarium root rot caused by Fusarium solani f. sp. phaseoli $(F s p)$ is widely distributed in Latin America. Experiments involving artificial inoculations could be better compared whether the number of $F s p$ infective propagules is well quantified by using chlamydospores. This study aimed to define the adequate concentration of chlamydospores of $F s p$ for assessment of the disease severity under controlled conditions. In greenhouse, two experiments were performed, where common bean susceptible genotypes were sown in a substrate infested with $0,1000,2000,3000,4000,5000$ or 6000 chlamydospores $\mathrm{g}^{-1}$ of substrate. Plants were rated for disease severity at $30 \mathrm{~d}$ after emergence. Linear response plateau was used to represent the relationship between disease severity and concentration of chlamydospores in the substrate. According to our results, concentrations between 4500 and 5000 chlamydospores g $^{-1}$ of substrate maximizes the disease severity and can be recommended to evaluate large-scale screenings of bean germplasm.
\end{abstract}

Key words: Fusarium solani f. sp. phaseoli, Phaseolus vulgaris, disease evaluation.

Fusarium root rot (FRR) caused by Fusarium solani f. sp. phaseoli W.C. Snyder \& H.N. Hansen $(F s p)$ is one of the most widely distributed diseases of common beans (Phaseolus vulgaris L.) in Latin America (Abawi \& PastorCorrales, 1990; Miranda et al., 2007; Toledo-Souza et al., 2009). In Brazil, the disease causes reduction of stand and plant growth and yield losses in the producing areas, especially in the irrigated fields of the cerrado region (Paula Júnior et al., 2006; Fernandes et al., 2010). The pathogen produces macroconidia, microconidia and chlamydospores as inoculum. While macroconidia play an important role at the pathogen dissemination by the wind, microconidia and chlamydospores are essential for the infection of host tissues (Katan et al., 1997). The chlamydospores are the long-term survival structures in soil and generally cause the primary infection on deep roots of beans (Nash et al., 1961).

There is no source of complete resistance to FRR, but partial resistance of the common bean germplasm has been reported (Tu \& Park, 1993; Schneider \& Kelly, 2000; Bilgi et al., 2008; Nicoli et al., 2012). Different methods have been used for screening common beans for resistance to this disease (Boomstra et al., 1977; Tu \& Park, 1993; Schneider \& Kelly, 2000; Chaudhary et al., 2006; Bilgi et al., 2008; Nicoli et al., 2012). According to Abawi \& Pastor-Corrales (1990), for greenhouse inoculations, Fsp conidia can be mixed into sterilized soil at concentrations of 3000 conidia $\mathrm{g}^{-1}$ of soil or higher. However, using of chlamydospores would be a more appropriate method for artificial soil infestation, since they are more effective than conidia as infective propagules (Counteaudier \& Alabouvette, 1990; De Cal et al., 1997). Reports of using chlamydospores as inoculum source of $F_{s p}$ are scarce and the adequate concentration of $F_{s} p$ chlamydospores in the substrate for large-scale screenings of bean germplasm in greenhouse is unknown. Our hypothesis is that experiments involving artificial inoculations could be better compared whether the number of $F s p$ propagules is well quantified by using chlamydospores. Thus this study aimed to define the adequate concentration of chlamydospores of $F_{s p}$ in the substrate for evaluating the severity of FRR under controlled conditions.

Two experiments were conducted in a greenhouse of the Plant Pathology Department, Federal University of Viçosa (UFV), State of Minas Gerais, Brazil. Fsp was isolated from common bean roots from a field of the Agricultural Research Institute of the State of Minas Gerais (EPAMIG) located in Oratórios, State of Minas Gerais, Brazil. This isolate recorded as $F s p-02$ was the most aggressive in preliminary tests compared with other $F s p$ isolates of the collection of the Plant Pathology Department (UFV). It was grown on potato-dextrose-agar (PDA) and stored at $10^{\circ} \mathrm{C}$ in the dark.

Chlamydospores of $F s p$ were produced according to Zambolim et al. (1983). Eight 8-mm-diameter Fsp discs from a 10-days-old PDA culture were placed into $250-\mathrm{mL}$ Erlenmeyer flasks containing $50 \mathrm{~mL}$ of soil extract. This 
soil was collected in an experimental area of UFV and was classified as Alfissol with the following characteristics at a depth of 0 to $0.20 \mathrm{~m}$ : $53 \%$ clay, $24 \%$ silt, $23 \%$ sand, $\mathrm{P}=$ $7.7 \mathrm{mg} \mathrm{dm}^{-3}, \mathrm{~K}=175 \mathrm{mg} \mathrm{dm}^{-3}$ (Mehlich 1), $\mathrm{Ca}=4.5 \mathrm{cmolc}$ $\mathrm{dm}^{-3}, \mathrm{Mg}=0.7 \mathrm{cmolc} \mathrm{dm}^{-3}\left(\mathrm{KCl}, 1 \mathrm{~mol} \mathrm{~L}^{-1}\right)$, and $\mathrm{pH}=5.8$. Soil $\mathrm{pH}$ was measured using a 1:2.5 soil-to-water ratio. Soil extract was prepared by autoclaving $500 \mathrm{~g}$ of soil in $1.0 \mathrm{~L}$ of tap water for 30 minutes, filtering the extract through filter paper, adjusting the $\mathrm{pH}$ to 6.5 with $\mathrm{CaCO}_{3}$, and then autoclaving at $121^{\circ} \mathrm{C}$ for 15 minutes. After incubation for 20 days at $26^{\circ} \mathrm{C}$ with a 12 hours photoperiod, the contents of the flasks were decanted onto a $37-\mu \mathrm{m}$ sieve and gently rinsed with tap water to separate chlamydospores and mycelia from the extract. The fungal mat was ground in a mixer for $30 \mathrm{~s}$. After dilution in series, the chlamydospores were mixed with sterilized dry sand in the concentration of $2 \times 10^{6}$ chlamydospores per gram of sand. Chlamydospores were maintained at $4^{\circ} \mathrm{C}$ before they were mixed with the substrate Plantmax $\mathrm{HT}^{\circledR}$ with a concrete mixer for $40 \mathrm{~min}$ to obtain the following concentrations of chlamydospores $\mathrm{g}^{-1}$ of substrate: $0,1000,2000,3000,4000,5000$ and 6000 . Substrate Plantmax $\mathrm{HT}^{\circledR}$ is a commercial substrate, made of pine bark, processed peat and vermiculite, with a $\mathrm{pH}$ of 5.8 and the following composition, in $\mathrm{g} \mathrm{kg}^{-1}: \mathrm{N}, 5.8 ; \mathrm{P}, 0.9$; $\mathrm{K}, 4.3$.

The substrate was put in $1.0 \mathrm{~L}$ pots, where seeds of the common bean susceptible genotypes BRSMG Majestoso (Experiment 1) and CNFP 10773 (Experiment 2) were sown. BRSMG Majestoso is a carioca bean cultivar (type II/III) recommended for the State of Minas Gerais since 2006. CNFP 10773 is a black type line (type III) of the UFV common bean germplasm. The experiments followed a randomized block design with five replicates. Each replicate was a pot $(1.0 \mathrm{~L})$ containing one plant. All treatments were irrigated once a day and received the same amount of water.

One plant per pot was rated for disease severity at 30 DAE, corresponding to R5 stage (pre-flowering) and the disease severity was expressed as the exact percentage of hypocotyls and root tissues covered with lesions, as suggested by Nicoli et al. (2012). After evaluation, linear response plateau was used to represent the relationship between disease severity and concentration of chlamydospores in the substrate, using the software "Sistema para Análise Estatística” (SAEG) (Ribeiro Júnior, 2001).

The linear response plateau model indicated that the highest disease levels were obtained when the inoculum concentration achieved about 4600 chlamydospores $\mathrm{g}^{-1}$ of substrate for BRSMG Majestoso (Figure 1A) and 4900 chlamydospores $\mathrm{g}^{-1}$ of substrate for CNFP 10773 (Figure 1B). The highest disease severity was $41 \%$ for BRSMG Majestoso and 37\% for CNFP 10773.

High disease severity can be found in naturally infested field soils with $F s p$ population density of 10003000 propagules $\mathrm{g}^{-1}$ of soil (Nash \& Snyder, 1962). Maybe because of that, Abawi \& Pastor-Corrales (1990) recommended concentrations of 3000 conidia $\mathrm{g}^{-1}$ of soil or higher for greenhouse inoculations. According to Miranda et al. (2007), the management of FRR in the field is hard when the inoculum density is higher than 1000 propagules $\mathrm{g}^{-1}$ of soil. In studies involving chlamydospores for inoculation of bean plants in greenhouse, concentrations between 4000 (Nicoli et al., 2012) and 5000 (Dhingra et al., 2006) chlamydospores of $\mathrm{g}^{-1}$ of substrate were used for $F s p$ and $F$. oxyxsporum f. sp. phaseoli, respectively.

Although the inoculation involving the production of chlamydospores takes more time than the procedures involving infested PDA discs, cereal grains colonized by

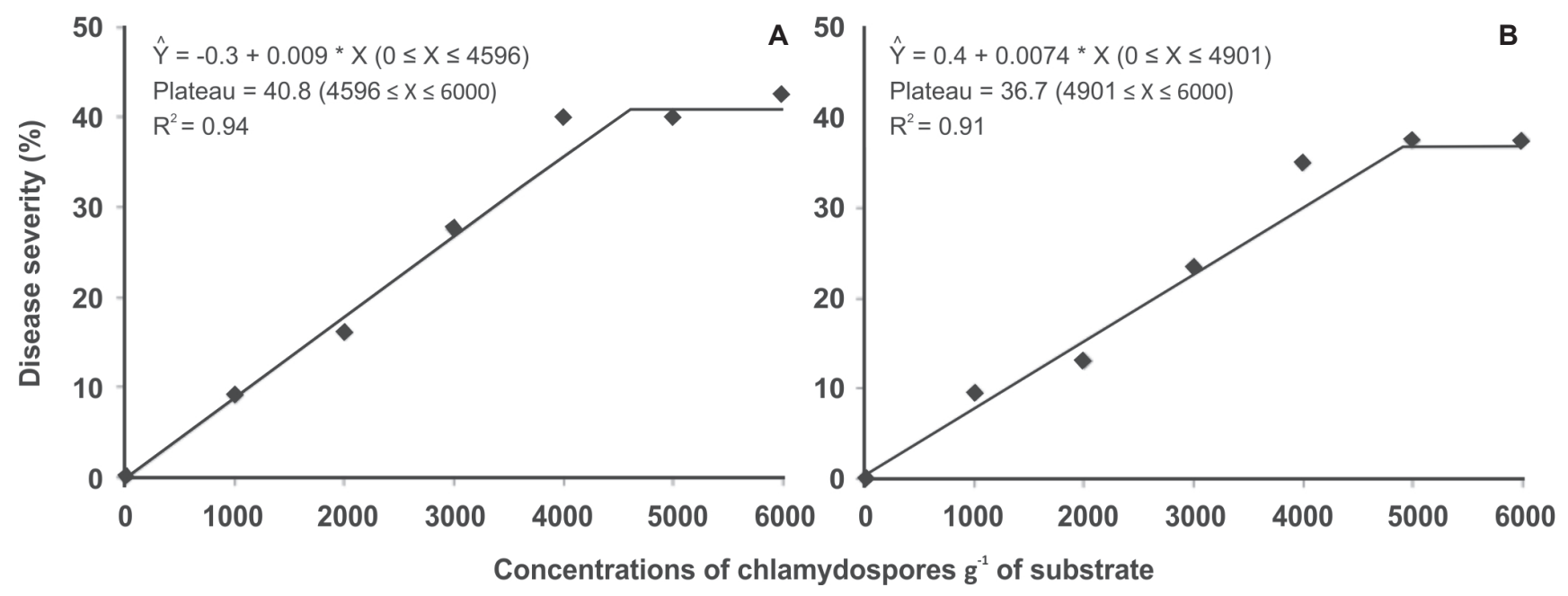

FIGURE 1 - Effect of concentrations of chlamydospores of Fusarium solani f. sp. phaseoli on the severity of Fusarium root rot on the common beans genotypes BRSMG Majestoso (A) and CNFP 10773 (B). Disease severity was expressed as the exact percentage of hypocotyls and root tissues covered with lesions. 
Fsp mycelium or conidia suspensions (Schneider \& Kelly, 2000; Chaudhary et al., 2006; Miranda et al., 2007; Bilgi et al., 2008), the results of controlled experiments can easily be compared provided that the number of $F s p$ propagules is quantified, as we did in our experiments. Our results suggest that the concentrations between 4500 and 5000 chlamydospores $\mathrm{g}^{-1}$ of substrate maximizes FRR severity and can be recommended to evaluate large-scale screenings of bean germplasm under controlled conditions.

\section{ACKNOWLEDGEMENTS}

A. Nicoli was supported by CAPES, Brasília, DF, Brazil. L. Zambolim, T. J. Paula Júnior, R. F. Vieira and J. E. S. Carneiro were supported by CNPq, Brasília, DF, Brazil. H. Teixeira was supported by FAPEMIG, Belo Horizonte, MG, Brazil. Research was supported by Empresa de Pesquisa Agropecuária de Minas Gerais - Epamig and Conselho Nacional de Desenvolvimento Científico e Tecnológico - CNPq.

\section{REFERENCES}

Abawi GS, Pastor-Corrales MA (1990) Root rots of beans in Latin America and Africa: diagnosis, research methodologies, and management strategies. Cali Colombia. CIAT.

Bilgi VN, Bradley CA, Khot SD, Grafton KF, Rasmussen JB (2008) Response of dry bean genotypes to Fusarium root rot, caused by Fusarium solani f. sp. phaseoli, under field and controlled conditions. Plant Disease 92:1197-1200.

Boomstra AG, Bliss FA, Beebe SE (1977) New sources of Fusarium root rot resistance in Phaseolus vulgaris L. Journal of the American Society for Horticulture Science 102:182-185.

Chaudhary TT, Anderson TT, Park SJ, Yu K (2006) Comparison of screening methods for resistance to Fusarium root rot in common beans (Phaseolus vulgaris L.). Journal of Phytopathology 154:303308.

Couteaudier Y, Alabouvette C (1990) Survival and inoculum potential of conidia and chlamydospores of Fusarium oxysporum f. sp. lini in soil. Canadian Journal of Microbiology 36:551-556.

De Cal A, Pascual S, Melgarejo P (1997) Infectivity of chlamydospores vs microconidia of Fusarium oxysporum f. sp. lycopersici on tomato. Journal of Phytopathology 145:231-233.

Dhingra OD, Coelho-Netto RA, Rodrigues FA, Silva Júnior GJ, Maia CB (2006) Selection of endemic nonpathogenic endophytic Fusarium oxysporum from bean roots and rhizosphere competent fluorescent Pseudomonas species to suppress Fusarium-yellow of beans. Biological Control 39:75-86.

Fernandes EC, Dalla Pria M, Silva OC (2010) Podridõesradiculares e murcha-de-fusarium. In: Dalla Pria M, Silva OC (Eds.) Cultura do feijão: doenças e controle. Ponta Grossa PR. UEPG. pp. 107-116.

Katan T, Shlevin E, Katan J (1997) Sporulation of Fusarium oxysporum f. sp. lycopersici on stem surfaces of tomato plants and aerial dissemination of inoculum. Phytopathology 87:712-719.

Miranda BA, Lobo Júnior M, Cunha MG (2007) Reação de cultivares do feijoeiro comum às podridões radiculares causadas por Rhizoctonia solani e Fusarium solani f. sp. phaseoli. Pesquisa Agropecuária Tropical 37:221-226.

Nash SM, Christou T, Snyder WC (1961) Existence of Fusarium solani f. sp. phaseoli as chlamydospores in soil. Phytopathology 51:308-312.

Nash SM, Snyder WC (1962) Quantitative estimations by plate counts of propagules of the bean root rot fusarium in fields soils. Phytopathology 52:567-572.

Nicoli A, Zambolim L, Paula Júnior TJ, Vieira RF, Teixeira H, Carneiro JES (2012) Resistance of advanced common bean lines to Fusarium root rot. Tropical Plant Pathology 37:393-398.

Paula Júnior TJ, Vieira RF, Lobo Júnior M, Morandi MAB, Carneiro JES, Zambolim L (2006) Manejo integrado do mofobranco do feijoeiro - Guia Técnico. Viçosa MG. Epamig-CTZM.

Ribeiro Júnior JI (2001) Análises estatísticas no SAEG. Viçosa MG. Editora Folha de Viçosa.

Schneider KA, Kelly JD (2000) A greenhouse screening protocol for Fusarium root rot in bean. HortScience 35:1095-1098.

Toledo-Souza ED, Lobo Júnior M, Silveira PM, Café Filho AC (2009) Interações entre Fusarium solani f. sp. phaseoli e Rhizoctonia solani na severidade da podridão radicular do feijoeiro. Pesquisa Agropecuária Tropical 39:13-17.

Tu JC, Park SJ (1993) Root rot resistance in common bean. Canadian Journal of Plant Science 73:365-367.

Zambolim L, Schenck NC, Mitchell DJ (1983) Inoculum density, pathogenicity, and interactions of soybean root-infecting fungi. Phytopathology 73:1398-1402. 